\title{
Fantastik Film Mekân ve Müziklerinin Eş Zamanlı Değerlendirilmesi: Edward Scissorhands (Makaseller) Örneği
}

Doç. Dr. İsmail Emre Kavut

Makale Geliş Tarihi: 21.04.2020 Öğr. Gör. Burçin Savaş

\section{Özet}

Mekân, fiziksel oluşumunun ötesinde düşünsel bir üründür. Şeffaflaşmış ve sııırları belli olmayan bu düşünsel boyut, özellikle fantastik film mekanlarında fiziksel mekan niteliklerinin farklılaşmasıyla daha net algılanmaktadır. Algısal mekanın sınırsızlı̆̆ı, akılcı bir gözle zihinde taranıp değerlendirildiğinde, bu tür filmlerdeki düşsel mekanlar somutlaşmaktadır. Fantastik filmlerde yaratılan bu kurmaca mekanların görsel tasarım algısına katkı sağlayan bir çok farklı disiplin olduğu gibi, film müziğinin yeri de tartışılamaz bir noktadadir.

Bu çalışma, müzik ve mimarlık arasındaki görsel ve işitsel dönüșümlere dair çalıșmalardan esinlenerek, mekch ve miziugi olusturan bel yoğurulmuş görsel etki ve işitsel boyutta onu destekleyen film müziği ile es zamanlı değerlendirildiğinde yoğurulmuş görsel etki ve işitsel boyutta onu destekleyen film müziği ile eş zamanlı değerlendirildiginde
bağdaşabileceklerini varsaymaktadır. Bu bağdaşıklığa dair inceleme, nitel araştırma yöntemleri ile elde bağdaşabileceklerini varsaymaktadır. Bu bağdaşıklığa dair inceleme, nitel araştırma yöntemleri ile elde
edilen veriler ışı̆̆ında, müzik ve mekan arasındaki biçimsel ilişkiyi analiz etmek amacıyla geliştirilen bir yöntem ile Tim Burton yönetmenliğindeki "Makas Eller" filminin seçilen sahnelerindeki mekan ve müziklerinin eş zamanlı karşılaştırması ile sonuca bağlanmıştır.

Anahtar Kelimeler: Fantastik Film, Mekan, Müzik, Tasarım

\section{SIMULTANEOUS APPRAISAL OF FANTASY FILM SPACE AND MUSIC:} EDWARD SCISSORHANDS

\section{Abstract}

Space is an intellectual product beyond its physical formation. This intellectual dimension, which has become transparent and has no clear boundaries, is perceived more clearly with the differentiation of physical space qualities, especially in fantastic film spaces. When the limitlessness of the perceptual space is scanned and evaluated in the mind with a rational eye, the imaginary spaces in such films become tangible. As there are many different disciplines that contribute to the visual design perception of these fangible. As there are many different disciplines that contribute to the visual design perception of these
fictional spaces created in fantastic films, the music of the film (Soundtrack) is also in an indisputable fictional spaces created in fantastic films, the music of the film (Soundtrack) is also in an indisputable point.

This study, inspired by the works on the visual and auditory transformations between music and architecture, assumes that the specific elements and arrangement principles that make up the space and music can be compatible with the soundtrack that supports it in the visual impact and auditory dimension. The investigation of this coherence was concluded with a method developed to analyze the formal relationship between music and space in the light of the data obtained by qualitative research methods, and a simultaneous comparison of the space and music in the selected scenes of the movie "Edward Scissorhands", directed by Tim Burton.

Keywords: Fantastic Film, Space, Music, Design 


\section{Giriş}

Film mekanları, tasarım aşamasında birçok farklı disiplin ile birlikte bir yaratım sürecinden geçmektedir. Bu disiplinler içerisinde müzik, filme ait senaryodaki mekan, zaman, hikaye ve karakter bağını desteklemekte ve görsel kompozisyonun tamamlayıcısı olabilmektedir. Film müziği ile film mekanları anlamsal boyutta bu kadar iç içe iken birbirleriyle biçimsel anlamda da benzeyebilmeleri söz konusu olabilir. Mekanın biçimsel tasarım kararları ile müziğin yapısı birbiri ile ilişkili olabilir. Bu ilişkinin incelenebilmesi için bu iki disiplinin ne noktalarda birbirleri ile benzerlikler taşıdığını araştıran M. N. Felix ve E. M. Elsamahy müziği görselleştirerek mimari üzerinde incelemeler yapmışlardır. Bu incelemelerde mimarlık ve müzik arasındaki yapısal ilişkiye dair ilk yorumlamaların, Antik Yunan dönemine dayandığını belirtmişlerdir. Alman düşünür Johann Wolfgang Von Goethe'nin "Mimariyi donmuş bir müzik olarak tanımlarım" şeklindeki söylemine ve 20.yy'da lannis Xenakis'in, matematiksel ilkelere ve geometrik yapılara dayanan kendi müzikal kompozisyon "modellerini" yaratarak müzik ve mimari arasındaki benzer yapısal ilkeleri incelemesine dayanarak, bu iki disiplinin birbirleriyle olan karşılıklı ilişkisi incelemişlerdir (Felix ve Elsamahy, 2016:1).

\section{Araştırma Strüktürü}

Görsel ve işitsel kompozisyonun birbirleri ile anlatılabileceğine dair yapılan bu tür araştırmalardan da yola çıkarak film mekanı ile film müziği arasındaki biçimsel ilişkiye dair incelemeye yönelik olan bu çalışmada aşağıdaki araştırma strüktürü oluşturulmuştur

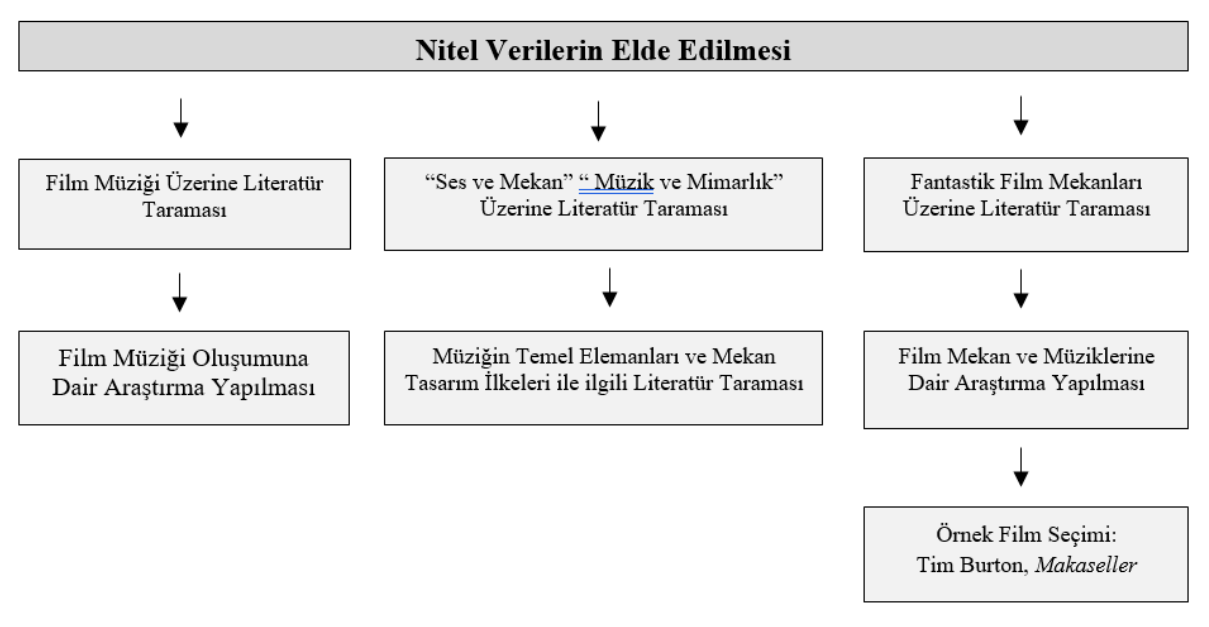

\begin{tabular}{|c|c|}
\hline \multicolumn{2}{|c|}{ Verilere göre Değerlendirme Yöntemi Belirleme } \\
\hline$\downarrow$ & $\downarrow$ \\
\hline $\begin{array}{l}\text { Fantastik Film Mekanı ve Film Müziğinin Birbiri ile } \\
\text { Biçimsel İliskilenebileceğgi Tasarmm Öğgelerinin } \\
\text { Belirlemesi ve tablo haline getirilmesi }\end{array}$ & $\begin{array}{l}\text { Seçilen örnek filmdeki mekan ve müziklerin es } \\
\text { zamanlı inceleneceği sahnelerin belirlenmesi }\end{array}$ \\
\hline \multicolumn{2}{|c|}{ Değerlendirme } \\
\hline \multicolumn{2}{|c|}{ SONUÇ } \\
\hline
\end{tabular}

\section{Bölüm: Genel Tanım ve Kavramlar}

Bilincin ve aklın yanı sıra duyguların da tasarıma dahil edilmesi tasarıyı eşsiz kılmaktadır. Tasarı bu sayede farklı beğenileri, hayat anlayışlarını, seçimleri, değer yargılarını ifade edebilir. Bu farklılıklar ölçülü ve katı kurallı evrenin keskin görüntüsüne öznel bir ışık tutar ve akla farklı bir yolla yaklaştırır. Bu yakınlaşma bazı tasarılarda birbiri ile olumlu bir rekabet içerisine girebilir. Bir tür dayanışma ile mekan yaratımı içerisinde düşten gelen unsurların sadeleşerek matematiksel bir şemanın içerisinde okutulmaya çalışılması söz konusu olabilir. Düş'ün sözlük anlamı uyurken zihinde beliren olayların, düşüncelerin bütünü, rüya veya gerçek olmayan şey, imge veya gerçekleşmesi istenen şey, umut olarak tarif edilir. ${ }^{1}$ Düşsel'in sözlük anlamı ise düş ile ilgili, hayali şeklinde tanımlanmaktadır. Tasarıda betimlenen düşlerin mekânsal bir anlam kazanması ve değerinin artması, "düşsel mekan"ı ortaya çıkarır. Gerçek olmayan ama olmuş ya da varmışçasına bellekte tasarlanan düşsel mekanlar somutlaştırılmak istendiğinde kurmaca mekanlara dönüşebilirler. Bu kurmaca mekanların gerçeküstü boyutu "fantastik film mekanlarını" oluşturmaktadır. Film, hareketli resimlerin seri şekilde gösterilmesi ile ortaya çıkan bir yapıttır. Gerçek insan ve objelerin kamerayla kayıt edilmesiyle veya animasyon teknikleri, özel efektler gibi teknikler ile her iki unsurun yaratılmasıyla ortaya çıkar. ${ }^{2}$ Fantastik filmlerdeki mekanların oluşumunu sağlayan fantezi, sinema, resim gibi çeşitli sanat dalları ve edebiyatta gerçek olmayan hikâyelerin anlatımıdır. ${ }^{3}$ Hayale dayalı, "düşsel" kalıpların dışındaki fantastik film mekanları sınırsızlıklarıyla her bir farklı açıda, eşsiz,

I 'TDK', http://www.tdk.gov.tr/index.php?option= com gts\&arama=gts\&guid=TDK. GTS. $51387 \mathrm{fb}$ c5e4db5.21781357. (2020, 0102$)$.

'TDK', http://www.tdk.gov.trlindex.php? ?option=com g gts\&arama=gts\&guid=TDK. GTS.5 $1387 \mathrm{fb}$ c5e4db5.2 178/357. (2020, 01 02)

3 'Vikipedi', https://www.wikizeroo. org/index.php?q=aHROcHM6Ly90ci53aWtpcGVkaWEub3JnL3dpa2kvRmFudGV6aQ. (2020, 01 05). 
biricik görsel kompozisyonlar yaratabilirler. Bu kompozisyonları yaratabilmek için mekanın öncelikle düşsel boyutunun yazılı olarak ifadesi iyi bir yol olabilir. Sonrasında sıralanmış betimlemeler çizilerek görselleştirilebilir ve imgelemin açığa çıkması sağlanabilir. Bu görselleştirme öznel olduğundan her tasarımcının belleğinde oluşan düşsel mekanın farklı sonuç ürüne dönüştüğünü gösterir nitelikte olacaktır. Şekil 1'deki diyagramda mekanı yaratan insanın, mekanın atmosferini değiştiren düşe bu vesileyle yakınlaşması, yaratılan mekanın kendine has nitelikleri, düşü yaratan insanın biçimlenmesini sağlaması, bu üç kavramın birbirleriyle yaratıcı süreçte akış halinde olmaları ortaya çıkacak düşsel mekanın ifadesi olmaktadır. Fantastik filmlerdeki kurgusal mekanlarda, düşsel boyutun açığa çıkması izleyicinin mekânsal algılarını ve düşüncelerini derinleştirir. Çağıışımlarda bulunmasını, içselleştirmesini, bakış açısını genişletmesini, düş kurmasını sağlar. Deneyimlenirken türlü şekillerde düşlerle katmanlaşır, sınırsız bir mekan algısına sebep olabilir. Bu durumda insanın düșe, düşün mekana, mekanın insana sürekli, tekrarlayan etkisinin ve bu iletişimin doğurduğu yaratımların varlığından söz etmek hiç de yanlış olmaz.

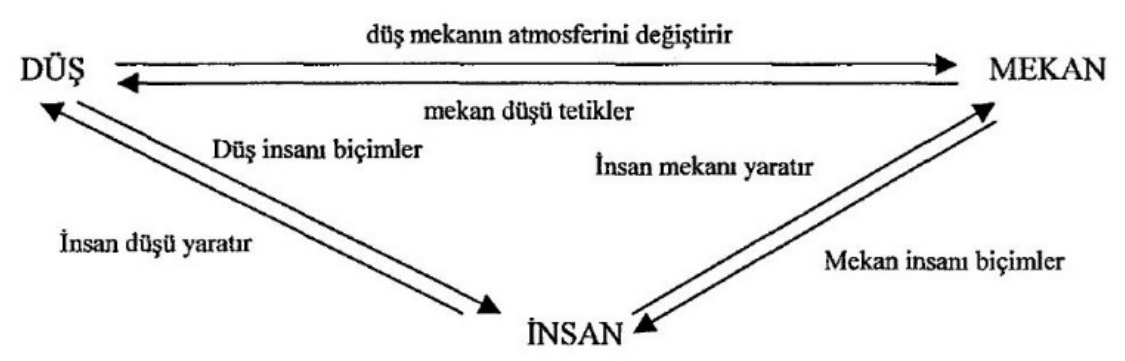

Şekil. I. Düş, Mekan ve İnsan İlişkisi (Demirbaş, 2000)

Fantastik film mekanlarının kavramsal sürreal doğası bu etkileşimin sonucu olarak karşımıza çıkmaktadır. Gerçek dışı algılanan bu mekanların kurgusunda zaman ve yer göz ardı edilerek oluşturulan düşsel mekanlar konu olmaktadır. Bu çalışmada da bir filmi üzerinden inceleme yapılacak olan yönetmen Tim Burton'ın filmlerindeki kurgu karakterler ve yaşadıkları karanlık, görkemli ve kasvetli mekânlar veya sıradan insanların yaşadığı hiç bir yere ait olmayan ve hiçbir zamandaki belirli kavramları sembolize eden şehirler bu sözü geçen kurgu mekanlara gösterilebilecek en iyi örnekler arasındadır.

\subsection{Film, Müzik, Zaman}

Mekanlaşan düş, bir mimari mekanın kurmacası olduğundan bazı kavram- lara göre ondan farklı özellikler taşıyabilir. Zamanın kısa veya uzun uzadıya dilimlenişi gerçek yaşam içinde mümkün değildir. Akıp giden zamanda yaşanılanlar, hafızamızda yarattığımız kesitlerde ancak yeniden ortaya çıkabilir. Zamanı geriye sarmak veya ilerletmek, değiştirmek, kısaltmak gerçek yaşamda mümkün değildir. Gerçek yaşamda zaman belirlidir. Ancak filmde yıllarca süren hikayeler bir saatte dahi anlatılabilir. İzleyiciye hafızadaki zaman diliminde hangi kesitin gösterilmesi istenirse o gösterilir. Bir başka deyişle; filmlerdeki kurgusal mekanlarda zaman kavramı, insan hafızasının kesintili görsel imgeleri gibi katmanlı bir boyutta dikey bir düzlemde incelenebilirken, mimari mekanda zaman, başından beri var olduğu ve süre geldiği yatay düzlemdeki tarihi ile açıklanabilir. Katmanlı bu boyut yönetmenin film mekanlarında belirlediği ve sunduğu görsel verilerin ışığında oluşurken, işitsel veriler de bu görsel verileri destekler nitelikte olmaktadır. Bu işitsel boyut sinema sanatında ses ve müzik olarak karşımıza çıkmaktadır. Geleneksel sinemada mekanın yalnızca görsel ve işitsel olarak tanımlanan bu iki özelliği algılanmaktadır. Görüntü, ses ve müzik film boyunca birbiri ile iletişim halindedir. Kimi zaman mekan kurgusunun görsel biçimlenişini işitsel öğeler desteklemekteyken, kimi zaman geri planda kalıp zemin değiştirmektedirler. Türkçede müzik genel tanımıyla, birtakım duygu ve düşünceleri belli kurallar çerçevesinde uyumlu seslerle anlatma sanatı; bu biçimde düzenlenmiş seslerden oluşan eserlerin okunması veya çalınması işidir. Türkçeye Fransızca yine müzik anlamına gelen musique kelimesinden girmiştir. ${ }^{4}$ Sinema ve televizyon terimi olarak ise, bir filmde ya da televizyon yayınında kullanılan, özgün ya da derleme her çeşit müziği anlatır genel terim olarak ifade edilmektedir (Sinema ve Televizyon Terimleri Sözlüğü-1981, 2020). Kant müziği "hoş duyguları sesle anlatma sanatı" olarak tanımlarken, edebiyat kuramcısı Mme de Staël müziği "seslerin mimarisi" olarak nitelemekte iken, müzik teorisyeni Jean-Jacques Rousseau ise müziği "sesleri kulağa hoş gelecek biçimde uyarlama sanatı" şeklinde tanımlamışır (Adlim, 1994'ten aktaran Doğan, 2009: 39).

Önceleri sadece görüntünün olduğu herhangi bir ses ve müzikle desteklenmeyen filmler sadece biçimlerin ön planda olduğu bir konumdayken, sesin filmde ilk kullanılışı 1920lerin sonunda gerçekleşmiştir. Müziğin filme eşlik etmesi ise 1895 'te sinematografın icat edilmesinden öncesine dayanmaktadır. Illk film müziği skoru da 1908 de Assassinat du Duc De Guise filmine bir klasik müzik sanatçısı olan Camille Saint tarafından yapılmışıı. ${ }^{5}$

4 "'TDK',http://www.tdk.gov.tr/index.php?option=com_gts\&arama=gts\&guid=TDK. GTS. $51387 \mathrm{fb}$ c5e4db5.2 1781357. (2020, 01 02)

5 'bilgibirikimi.net', bilgibirikimi.net: https://bilgibirikimi.net/201 I/06/26/ilk-sesli-film-ne-zaman-cevrilmistir/. (2020, 01 02). 


\section{Bölüm: Fantastik Film Mekan ve Müziklerinin Es Zamanlı} Değerlendirilmesi: Edward Scissorhands (Makaseller) Örneği

Film, müzik ve mekanın zaman kavramı ile bir arada ilerleyebilmesi adına müziğin belirli işlevleri söz konusudur. Bu işlevler sırasıyla hikayeye odaklama ve sürükleyiciliği sağlama, tanıtma ve betimleme, filmi ve konusunu çağrıştırma, ilgi çekme ve eğlendirme, çerçeveleme, doruk noktalarına vurgu yapma gibi sıralanabilir. Bu işlevlerin yanı sıra aynı zamanda coğrafyayı, kültürü belirten, anlamı destekleyen, atmosferi belirten, duyguyu destekleyen, vurgulayan, dolduran, geçiş sağlayan, canlılı̆̆ vurgulayan, kurguyla eşleşebilen, gerilim veya doğallık hissettirebilen, zamansal geçişi anlatabilen bir yapısı da vardır (Doğan, 2009:133). Film müziği bu gibi özellikleri ile görüntüyü dillendirdiğinden, mekanla eş zamanlı incelendiğinde mekansal özelliklere anlamsal veya biçimsel anlamda da bağlanabilir. Ünlü film müzikleri bestecisi Hans Zimmer mekan tasarımcılarının, aktörlerin, yazarların, bestecilerin bir film için yepyeni bir dünya yarattığından bahsetmektedir. Bu yaklaşım bir filmin oluşumu için farklı disiplinlerin yarattığı ortak kurgunun, temanın, kavramsal mekanı oluşturduğu gibi film müziğine de aynı izde yansıdığına dair bir söylem olarak kabul edilebilir Müzik, kullanılan işlevlerin yardımı ile mekanlar üzerine biçimlenir, melodi ve orkestrasyon belirli anlamları ve filmin kavramsal yaklaşımını destekler. Bazen karakterleri, bazense belirli olayların karakterlere yansıyan duygu durumlarını temsil eder. Belirli bir tema ile kurgulanmış mekanın atmosfer algısına katkıda bulunur. Film müzikleri ve mekanları birbirleriyle kurdukları bu anlamsal bağ ile birbirleriye özdeşleşebilirler. Herhangi bir görsel algı olmaksızın müzik bellekte o filmin hikayesini, karakterin bir hareketini, bir mekanda geçen olay dizisinin imgelemini yaratabilir. Aynı şekilde bazı film mekanları, müziğiyle anlamsal açıdan öyle bütünleşmiştir ki, o sahneyi o melodi olmadan düşünmek mümkün olamayabilir. Bu bütünsel algı mekan ve müziğin filmdeki ana tema ile kavramsal bağdaşıklığından kaynaklanabilir. Fantastik ve gotik sinema'nın öncülerinden Tim Burton'ın yönetmenliğinde başrollerinde Johnny Depp ve Winona Ryder'ın oynadığı 1990 yapımı, film müziklerini Danny Elfman'ın yapmış olduğu modern bir masalın izleyiciye anlatıldığı kültleşmiş klasik bir fantazi kurgu olan Makas Eller'de bu tarz karvramsal bağdaşıklıklar mevcuttur. Karşıt kavramların bir arada sunulduğu hikayede, bu kavramları destekleyen, hikayeyi yaşatan, mekanla bağ kuran ve o mekanı unutulmaz kılan film müzikleri söz konusudur. Şekil 2'de öyküdeki kadın karakterin, kurgu karakterle karşı karşıya kaldığı sahnedeki, kurgu ve gerçeğin zıtlığı, beyaz ve siyah karşıtı̆ğı, sahnedeki parlak ve yoğun karanlık mekana zıt bembeyaz yağan kar taneleri yavas ve sakin ritmin üzerine duyulan aceleci staccato notalar ile benzeşmektedir. Müzikteki zıtlık, hikayedeki kavramsal zıtlıkla bağdaştığı gibi kadın karakterin uçsuz bucaksız hacimdeki mekana karşı ellerini havaya açıp dans etmesi ile mekanın hacmini hissettirirken, yağan küçük kar tanelerini betimleyen kesik kesik notalar ile geniş ve uçsuz karanlık mekanı tasvir eden uzun leggato notaların eşsiz uyumlu armonisinin mekan ve öyküyle kurduğu bağıntı ise müzik ve sahnenin biçimsel bağdaşıklığından kaynaklı olabilir. Öyle ki müzik ile uyumlu olan sahnenin biçimsel kompozisyonu her bir geometriyi daha çarpıcı bir boyuta taşımaktadır.
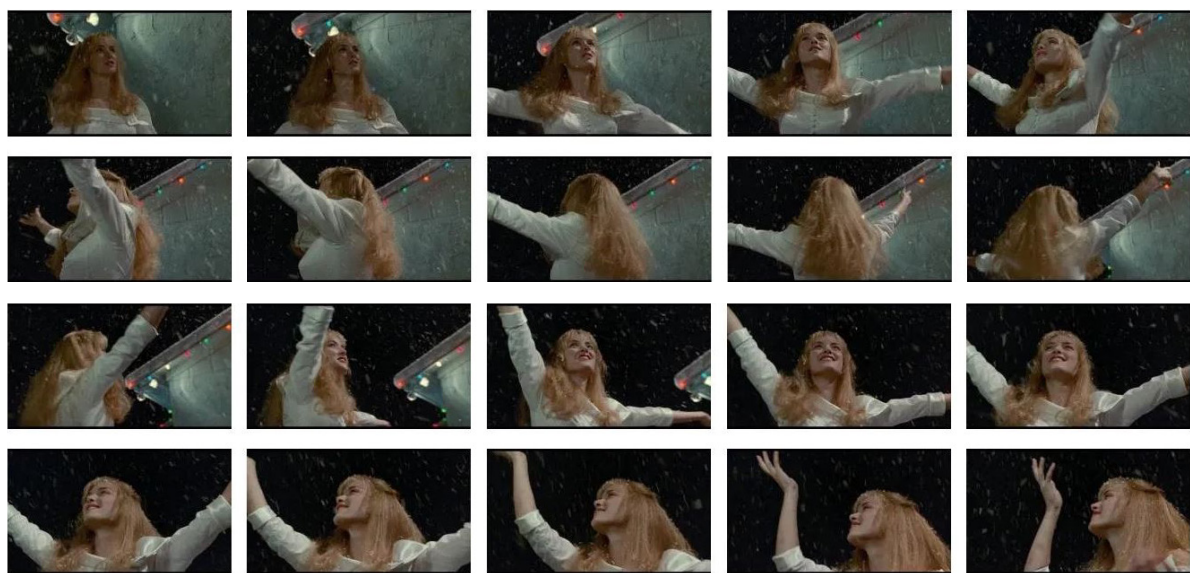

Şekil 2. Makaseller 1:16:27 - I:16:36 dakikalar arası "Ice Dance" isimli film müziğinde, mekan, öykü ve karakter bağı

Alman düşünür Johann Wolfgang Von Goethe'nin "Mimariyi donmuş bir müzik olarak tanımlarım" şeklindeki söylemi, müzik ve mimarlık arasındaki biçimsel dönüşümlere bir ilham olsa da bunu film müzikleri ve mekanları üzerinde inceleyebilmek için, bu iki disiplinin birbirleriyle olan benzerliklerinin daha detaylı araştırılması gerekli görülmüştür. "Fantastik filmlerde mekan ve çarpıcı bir işitsel öğe olan film müziği, anlamsal olarak ilişkilendiği gibi, iki disiplinin birbirlerine eş bir takım düzenleme ilkeleri ile de fiziksel anlamda da bağdaşabilir" hipotezi, bu araştırmanın yapılmasına zemin hazırlayan temel düşünce olmuştur. Bu biçimsel bağdaşıklığın var olabileceğine dair düşüncenin araştırılması adına toplanan veriler ışığında film müziği ve film mekanının arasında yapılacak karşılaştırma sırasında ilişkilenebileceği düşünülen terimlerin tanımlamaları yapılmak üzere Tablo 1 'de sıralanmıştır. 
Biçim, Renk, Oran, Ritim, Zıtlık, Hiyerarşi, Vurgu, Baskınlık, Denge, Şekil-Zemin

İlişkisi

Dinamikler, Artikülasyon, Telli / Yaylı Çalgılar, Üflemeli Çalgılar Vurmalı Çalgılar, Melodi, Ritm, Tizleşme, Pesleşme

Tablo I. Filmde Mekan - Filmde Müzik karşılaştırması için gereken terimler listesi

\subsection{Filmde Mekan İçin Tanimlamalar}

Biçim: Bir tasarımın dış sınır çizgileri o tasarımın biçimini oluşturur. Bu çevre çizgileri hem iki boyutlu hem üç boyutlu cisimler için geçerlidir. Bir objeyi oluşturan en dıştaki çizgisel şablon biçimi oluşturur.

Renk: Işık renk ile bağıntılıdır. Gözümüze yansıyan ışığın etkisi ile renk oluşur. Renklerin birbirleriyle yakın veya uzak ilişkilerine bağlı olarak bazı sınıflandırmaları mevcuttur. Sarı, mavi, kırmızı renkler ana renkler olup, turuncu, mor ve yeşil ara renkler olarak sınıflanmaktadır. Mor ve sarı, mavi ile turuncu, kırmızı ile yeşil ise birbirine zıt, birbirlerini tamamlayıcı renklerdir. Renk çemberinde yanyana olan renkler ise anolog (komşu renkler) olarak adlandırılmaktadır. Sarı, sarı - yeşil, sarı - turuncu, kırmızı, kırmızı - turuncu, kırmızı- mor bu renklere örnek olarak gösterilebilir. Bütün renklerin bu şekilde isimlendirilmelerinin nedenlerinden biri etkileridir. Analog renkler birbirine benzerler bu nedenle kullanıldıklarında sakinleştirici ve dingin bir hava yaratırlar. Zıt renkler birbirlerini parlatır ve öne çıkarırlar. Tüm bu renkler komşu, zıt, ana ve ara renkler renk armonileri ile uyumlu birleşimler yaratabilirler. Bunların yanı sıra renkler sıcak ve soğuk renkler olmak üzere ikiye ayrılır. Sıcak renkler: Kırmızı, turuncu, sarı ile içinde bu renkleri çokça bulunduran renklerdir. Soğuk renkler ise mavi, yeşil ve mor renkler ile içinde bu renkleri çokça bulunduran renklerdir. Rengi üç başlık altında incelenebilir. Rengin türü, bir rengi tanıyıp tanımlamakta kullandığımız özellik, örneğin kırmızı, sarı veya mavi olarak adlandırmamız gibiyken, rengin değeri, bir rengin koyuluk veya açıklık derecesidir. Renk beyaza yaklaştıkça açılır, siyaha yaklaştıkça koyulaşır. Üçüncü olarak rengin doygunluğu veya saflığı ise, o rengin tonunu oluşturan unsurların, renk içinde ne kadar derişik ya da seyreltik bulunduğudur. Renk saflaştıkça ve kendi öz rengine döndükçe parlar ve yoğunlaşır, seyreldikçe de matlaşır ve şiddeti azalır.
Oran: Oran bir parçanın değeri veya bütünü ya da bir objenin diğeri ile olan ilişkisini gösterir bu ilişkiyi büyüklük, nicelik veya dereceden birisini ifade eder. Bir objenin algılanan boyutları kendi çevresindeki diğer objelerin göreceli boyutlarından etkilenir

Ritim: Ritmin tasarım ilkesi, öğelerin mekan ve zaman içinde tekrarına dayanır. Bu tekrar hem görsel bütünlük oluşturur, hem de ritmik bir hareket sürekliliği yaratır.

Zıtlık: Zıtlık bir tasarımda bir taraftan uyuşmazlık doğururken diğer taraftan tasarıma canlılık verici bir görev yapar. Yön, değer (ton), biçim, ölçü, yön, aralık, renk bakımından zıtık yaratılabilir.

Vurgu - Baskınlık: Önemli bir öğenin, anlamlı derecede boyutlandırılarak, kendine has bir şekil verilerek veya kompozisyonda karşıt bir renkle, tonla veya dokuyla donatılarak görsel anlamda vurgulanabilir. Bir kompozisyondaki baskın öğe veya özellik, ikincil öğelerle veya özelliklerle arasında ayırt edilebilir bir karşıtlık kuruyor ise vurgu tasarım ilkesi algılanıyor demektir. Bu tasarım ilkesi kompozisyonun normal düzenini duraklattığı için dikkat çekmektedir.

Hiyerarşi: Bir biçim boyut, şekil, konum olarak farklılaşıp baskın eleman haline gelebilir ve kompozisyondaki diğer elemanlara göre daha önemli bir hale gelebilir. Bu durumda kompozisyonda hiyerarşik yapı oluşabilir.

Şekil - Zemin İlişkisi: Göz bir objeyi çevresinden farklılaştırdığı ve ayırdığı durumda şekil ve zemin arasındaki ilişki okunmaya başlar.

Denge: Denge hem benzer hem de benzeri olmayan elemanlar arasında dikkatli düzenlemeleri amaçlar. Dengenin üç türü vardır. Bunlar simetrik, radyal ve asimetrik dengedir. Simetrik denge eş değer elemanların biçim, ölçü ve göreceli kavramlarına göre, ortak çizgi ya da aksa göre yerleşmeleridir. Radyal denge ise merkezi bir noktaya göre elemanların yerleştirilmesinden oluşur. Ortadaki alanı bir odak noktası olarak belirginleştiren merkezi bir kompozisyon oluşturur. Elemanlar merkeze doğru odaklanarak yerleşirler veya merkezi bir elemanın etrafında yer alırlar.

Asimetri ise bir kompozisyonun elemanları arasında boyut biçim renk veya göreceli konumları arasındaki bağlantıların yoksunluğu olarak tanımlanır. Simetrik bir kompozisyon eşdeğer eleman çiftlerine gereksinirken asimetrik bir kompozisyon benzeri olmayan elemanları bir araya getirir (Güngör, 2020). 
2.2.Filmde Müzik İçin Tanimlamalar

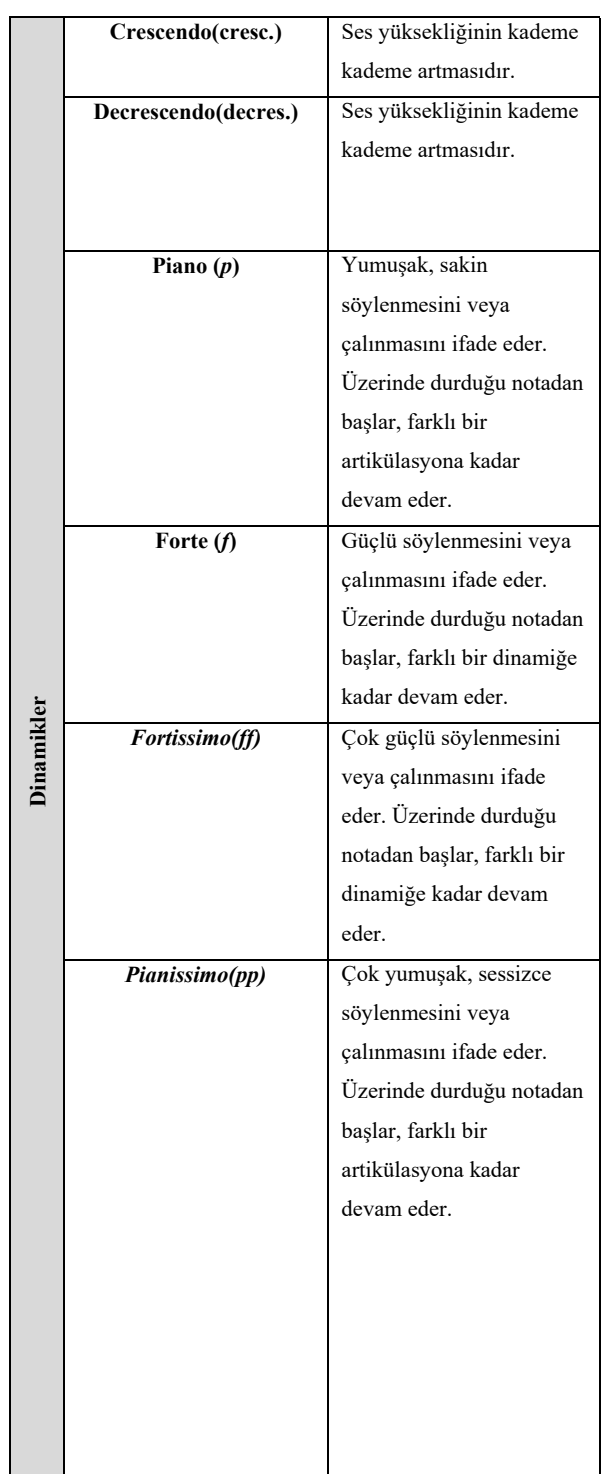

\begin{tabular}{|c|c|}
\hline Güçlü atak & $\begin{array}{l}\text { sforzando } \\
(s f)\end{array}$ \\
\hline $\begin{array}{l}\text { Notaların kesik kesik çalınacağı̆ıı } \\
\text { ya da söyleneceğini belirtir. }\end{array}$ & $\begin{array}{l}\text { Staccato } \\
(\cdot)\end{array}$ \\
\hline $\begin{array}{l}\text { Notaların, ara vermeksizin } \\
\text { birbirine bağlanarak çalınacă̆ııı } \\
\text { ya da söyleneceğini belirtir. }\end{array}$ & $\begin{array}{c}\text { Legato } \\
(-)\end{array}$ \\
\hline $\begin{array}{l}\text { Müziğin gövdesidir, notaların } \\
\text { uyumlu dizilisidir. Ritim ve } \\
\text { melodi bir araya geldiğinde tek } \\
\text { sesli müziği meydana getirir }\end{array}$ & Melodi \\
\hline $\begin{array}{l}\text { Müziğin iskeletini } \\
\text { oluşturmaktadrr. Melodiye eşlik } \\
\text { eder. }\end{array}$ & Ritim \\
\hline $\begin{array}{l}\text { Frekans (Sesin saniydeki titreşim } \\
\text { sayısı) arttıkça ses tizleşir. }\end{array}$ & Tizleşme \\
\hline Frekans azaldıkça ses pesleşir. & Peslessme \\
\hline $\begin{array}{l}\text { Keman, Viyola, Viyolonsel, } \\
\text { Kontrbas, Arp }\end{array}$ & $\begin{array}{c}\text { Telli / Yaylı } \\
\text { Çalglar }\end{array}$ \\
\hline $\begin{array}{l}\text { Tahta Üflemeli Çalgılar: Flüt, } \\
\text { Obua , Klarinet, Fagot } \\
\text { Bakır Üflemeli Çalglar: Korno, } \\
\text { Trompet, Trombon, Tuba }\end{array}$ & $\begin{array}{l}\text { Üflemeli } \\
\text { Çalgilar }\end{array}$ \\
\hline Timpani, Zil, Davul, Çan, Piano & $\begin{array}{l}\text { Vurmalı } \\
\text { Çalgılar }\end{array}$ \\
\hline
\end{tabular}

Tablo 2. Filmde Müzik için tanımlamalar

\subsection{Makaseller Görsel Analiz}

Bu bölümde Makaseller filminin belirli sahnelerinde, mekandaki tasarım öğelerinin, müzikteki değişimlerle eşleşip eşleşmediğini incelemek adına bir görsel analiz çalışması yapılmıştır. Sonuç bölümünde aynı sahnelerdeki müziğin görsel analiz ile karşılaştırması yapılacaktır.

\subsubsection{Renk}

Makaseller filminin hikayesindeki iki zıt dünyaya uygun bir biçimde, ilişkili sahnelere ait iki ayrı renk paleti bulunmaktadır. Pastel, beyaza giden birbirine yakın renklerin kullanıldığı sahneler hikayenin sıradan ve görünürde neşeli ve mutlu görünen banliyö yaşamını temsil etmekte olup, onlara zıt koyu renkli sahneler ise gizemli, ürkütücü karanlık bir dünyayı temsil etmektedir. Şekil 3'te 26:42 - 26:54 dakikaları arasındaki renkli olarak tanıtılan banliyö yaşamının sıradan ve aynılaşmıs dünyasının renk şemas görülmektedir. Renk şemasında ana renkler ve her bir ana rengin komşu renkleri kullanılarak geniş bir renk armonisi elde edilmiş, renklerin çoğu turunculaşarak saflığı azaltılmış ve beyaza belirli oranlarda yaklaştırılmıştır.
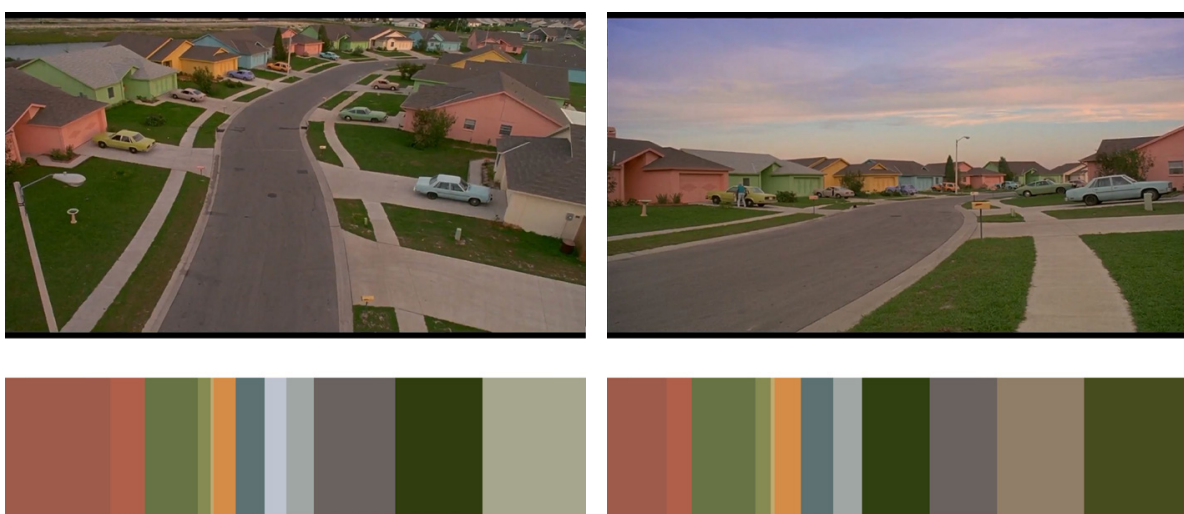

Şekil 3. Makaseller 26:42 - 26:54 Dakikaları Arası Renk Ayrıştırması

Makaseller filmindeki renk kullanımının müzik ile ilişkisini incelemek adına bu Şekil 3'teki sahnelerin zıttı olarak kabul edilebilecek, filmin koyu renklerinin hakim olduğu, hikayenin karanlık dünyasının tasvir edildiği 9:15 ile 9:28 dakikaları arasındaki sahneler seçilmiştir. Şekil 4'te genel renk şeması görülen bu sahnelerdeki müzik ile rengin doygunluğu, saflığı, şiddeti, miktarı, türü, değeri karşılaştırılarak "Müziğin mekanda renk ile ilişkisi" grafiklerle değerlendirilmiştir.
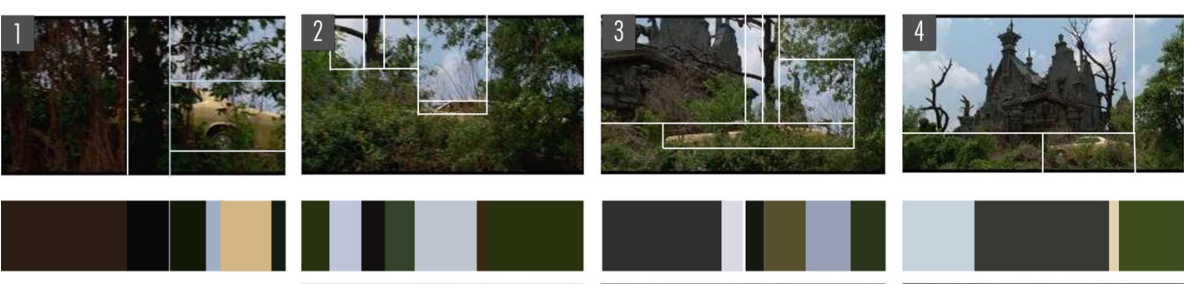

Şekil 4. Makaseller 9:15 - 9:28 Dakikaları Arası Sahneler ve Renk Ayrıştırmaları 
Renk şemasındaki renkler asıl olarak iki ana renk olan sarı ve mavi ile ikisinin birleşiminden elde edilen bir ara renk olan yeşilden oluşmaktadır. Fakat tüm bu renklerin doygunluğunun, şiddetinin, saflığının değiştirilerek kullanılması söz konusudur. Şekil 5'te görülen grafik, renklerin doygunluk oranını göstermektedir. Doygunluk oranı zamanla ilişkilendiğinde, rengin en saf olduğu " 0 " noktasından ne kadar yukarı çıkarsa o kadar ana renk kirlenmiş ve rengin şiddeti azalmıştır. Grafiğe göre çoğunlukla renklerin belirli oranlarda matlaşmış ve doygunluğunun azaltılmış olduğu gözlemlenmektedir.

\section{DOYGUNLUK ORANI}

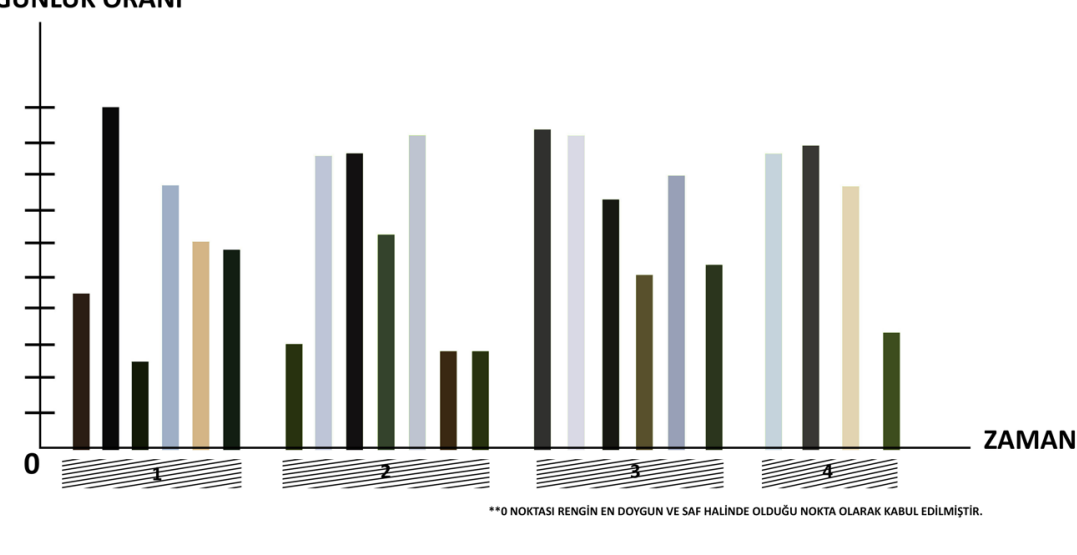

Şekil 5. Makaseller 9:15 - 9:28 Dakikaları Arası Sahneler Rengin Doygunluğu-Saflı̆̆ı-Şiddeti Grafiği

(0 noktası rengin en doygun ve saf halinde olduğu nokta olarak kabul edilmiştir)

Kırmızı, mavi, sarı ve yeşilin farklılaşması ile oluşan renk paletinde sahneler geçtikçe renk türlerinin miktarında azalma veya artma olduğu gözlenmiştir. Buna göre oluşturulan Şekil 6'daki rengin türü ve miktarını gösteren grafikte, son karelere doğru mavi ve yeşil rengin miktar olarak 1. kareye göre arttığı, sarı rengin miktarının ise oldukça azaldığı gözlenmiştir. Bu azalmaya rağmen 4. karede sıcak renklerin oranı, soğuk renklerden bir kaç birim daha fazladır. 1.karede ise sarı renk ve tonlarının miktarı fazla olduğundan sıcak renklerin oranının fazla olduğu gözlenmektedir.

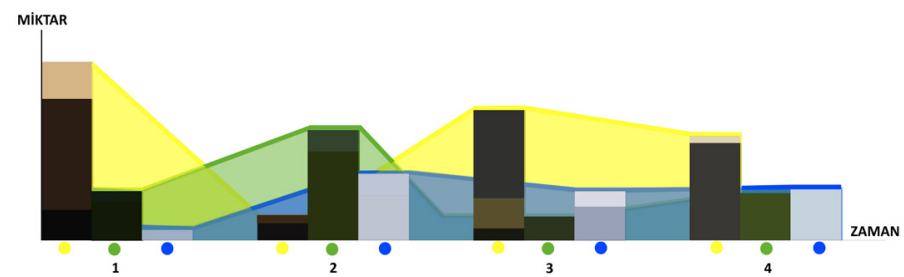

Şekil 6. Makaseller 9:15 - 9:28 dak. Arası Sahneler Rengin Türü ve Miktarı Grafiği
Rengin doygunluğu ve miktarının farklılaşması gibi sahne geçişlerinde rengin değerinde de farklılaşma gözlemlenmektedir (Şekil 7). Şekil 8'de görülen 1. kareden 4. kareye kadar olan renk değerinin değişim grafiğinde renklerin 1. karede neredeyse yarısının siyaha en yakın değerlerde olduğu, 2. kareden sonra ise sıklaşan bir ritim içerisinde, koyulma ve açılmalar içermiş olduğu gözlenmektedir. 4. kareye doğru ise iniş çıkışların sıklaştığı bir renk değer grafiği çizgisi görülmektedir.
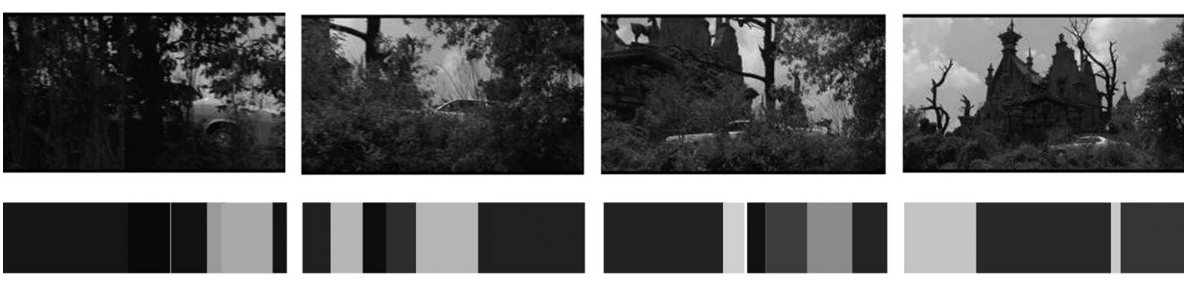

Şekil 7. Makaseller 9:15 - 9:28 Dakikaları Arası Sahneler Ve Renk Değeri Ayrıştırmaları

Şekil 8. Makaseller 9:15 - 9:28 dakikaları Arası Sahneler, Renk Değerinin Değişim Grafiği

\subsubsection{Biçim ve Oran}

Şekil 9'da görülen 9:15 - 9:28 dakikaları arası sahnelerin siyah beyaz biçimsel anlatımı üzerinden yapılan noktasal ve çizgisel analizin 4. karesinde ortaya çıkan sıklaşmış, tekrar eden noktaların oluşturduğu çizgiler yoğun bir görsel doku algısına sahiptir. Şekil 10'da ise aynı zaman aralığındaki sahnelerdeki şekillerin oranları ele alındığında, 4. karedeki şekil algısı hiyerarşik bir düzen içerisindeki süreçte en büyük ebattadır.
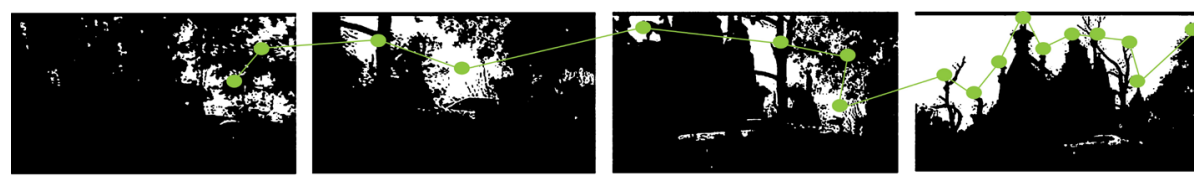

Şekil 9. Makaseller 9:15 - 9:28 Dakikaları Arası Sahnelerde Noktasal ve Çizgisel Analiz
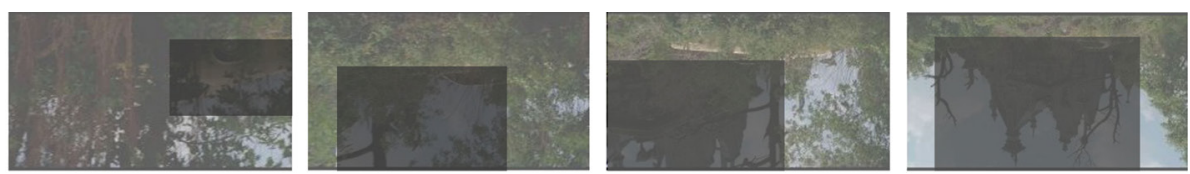

Şekil 10. Makaseller 9:15 - 9:28 Dakikalar Arası Sahnelerdeki Oran 
Filmde bazı sahnelerde insan ölçeğini hissettiren bakış açıları mevcuttur. Şekil 11'de mekanların derinliğini, yüksekliğini ve genişliğini hissettiren görüntüler, mekanlar ve insan ölçeği arasında kurulan güçlü yakınlaştırmalardan kaynaklanmaktadır. Bu sayede mekanların hacmini algılamak ve oransal anlamda yapı ve insan arasındaki ilişkiyi algılamak mümkündür.
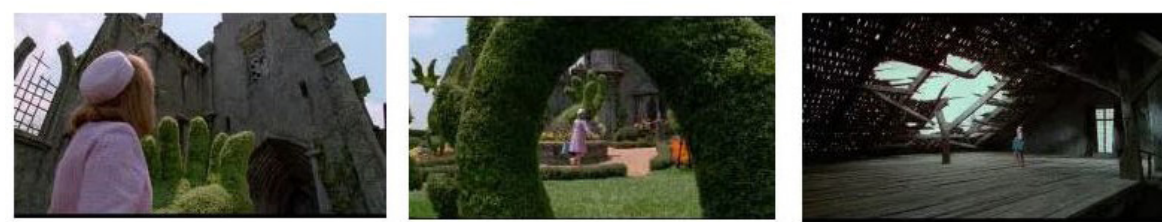

Şekil II. Makaseller Film Mekanlarında İnsan Ölçeği

2.3.3. Ritim

Şekil 12'de görülen 26:48 - 27:23 dakikaları arası sahnelerde, bir eksenin iki yanında aynı veya farklı uzaklıkta birbirleriyle ilişkili biçimlerde ritim ilkesi görülmektedir. Tek düze renkli pastel evler hacimsel olarak, çevresindeki tanımlı alanlar ise düzlemsel olarak ritmik bir dizilim içerisindedirler.
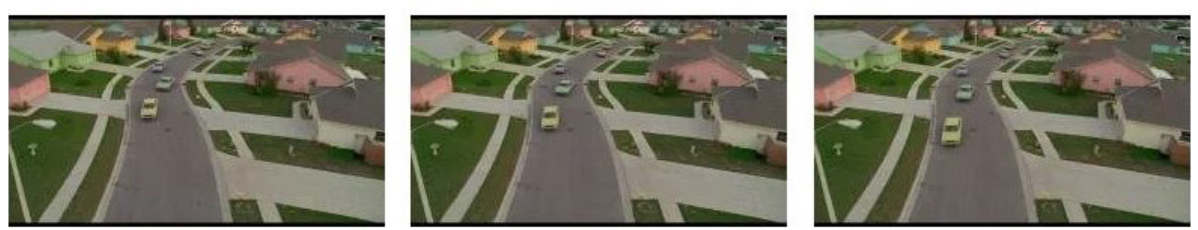

Şekil I2. Makaseller 26:48 - 27:23 Dakikalar Arası Sahnelerdeki Ritim

\section{Sonuç}

Makaseller 9:15 - 9:28 dakikaları arasındaki sahnelerde yapılan görsel analiz çalışması aynı dakikalardaki film müziği ile karşılaştııımışıı. Renk, biçim, oran ve ritim bağlamında incelenen görsel analiz, işitsel karşılıklar ile incelenmiştir. Yapılan değerlendirme sonucunda "Renk ve Müzik", "Biçim, Oran ve Müzik", "Ritim ve Müzik" arasındaki bağıntıya dair çıkarımlar yapılmıştır. Şekil 4'te numaralanmış sahneler anlatımlar yapılmıştır.

"Renk ve Müzik" üzerine yapılan çıkarımlara göre;

- 1. karede bulunan sahnede müzik, vals ritminin üzerine biçimlenmiş, yaylılarla çalınan staccato melodinin etkisinde, sade ve merak uyandıran bir halde ilerlerken, 4. karedeki sahneye gelindiğinde üflemeli çalgıların da (fagot, flüt) müziğe eklenmesiyle daha doygun ve etkisi șiddetli bir hale gelmektedir. Şekil 5 'teki rengin doygunluğu-saflığı-şiddetine dair grafik çalışmasından da hareketle Şekil 13'de müzik ve rengin doygunluk bağlamında ilişkisi değerlendirilmiştir. Görüldüğü üzere gittikçe şiddeti artan bir süreç içerisindeyken müzik, rengin şiddeti tüm sahnelerde homojene yakın bir dağılım göstermiştir. Bu durumda rengin doygunluğunun değişimi müzik ile aynı bağıntıda gitmemiştir. Birbirlerinden bağımsız hareket etmişlerdir.

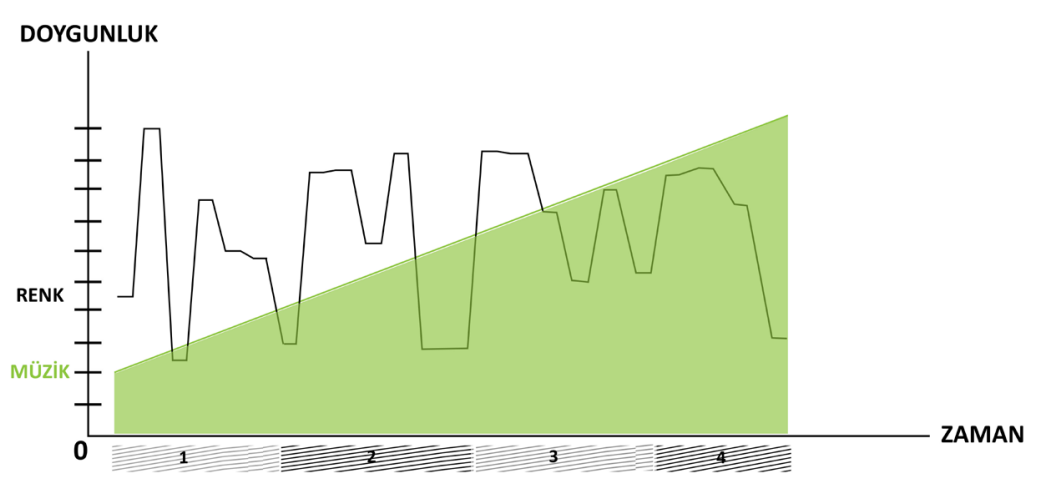

Şekil 13. Müzik ve Rengin Doygunluk Bağlamında Ilişkisi

- Soğuk renkler daha geri planda kalan, sıcak renkler ise daha ön planda algılanan renkler olarak düşünüldüğünde, Şekil 14'te görülen müzik ve renk türü grafiğinde müziğin çeşitlendiği, coşku ile ürperttiği, crescendo yaparak ön planda olduğu ve açığa çıktığı sahne olan 4 . karede, sıcak renklerin ve soğuk renkler dengededir. Bu parametrede de rengin miktarı ve türü, müzik ile baskınlık bağlamında benzer ilişkide gitmemiştir. Birbirlerinden zıt hareket etmişlerdir. Parlak renklerin müziğin baskın olmadığı 1. Karede ön planda olması, 4. Karede ise tüm renklerin birbirine yakın olup dengede olması müziği daha da ortaya çıkarmıştı. Görsel algıda rengin nötralize olması işitsel öğenin ön plana ve baskın öğe olarak ortaya çıkmasına katkı sağlamaktadır.

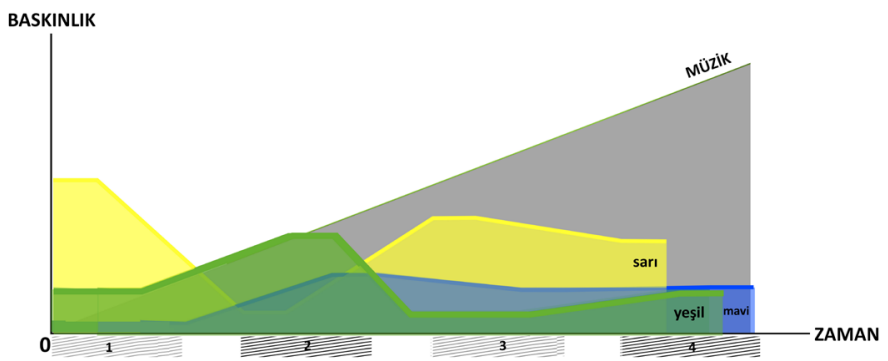

Şekil I4. Müzik ve Rengin Türü - Miktarının Baskınlık Bağlamında Ilişkisi 
- Şekil 8'de görülen renk değer değişim grafiğinde olduğu gibi 1. Karedeki siyaha yakın değererin 4. kareye doğru bir ritim içeirsinde koyulma ve açılmalar görülüor olması aynı dakikalardaki müzikteki ritmin üzerine kısa vuruşların hızlıca oturması ile benzeşmektedir. Legato notalar ise 4. karede oran olarak artan koyu renklerin derinliğini pekiştirmektedir. Buradan müzikteki artikülasyonun koyu renkler arttıkça değiş̧iği düşünülürse, bu benzeşmelere göre Şekil $15^{\prime}$ deki grafikte müzikte artikülasyon ve renk değeri ilişkilendirmesi yapılmıştr. Renk değerinde açılma oldukça staccato, koyulaşma oldukça leggato notaların olması, nota değeri kısaldıkça rengin değerinin beyaza yakınlaşması, uzadıkça da rengin değerinin siyaha yakınlaşması söz konusudur. Bu durumda renk değeri ve müzikteki artikülasyon her birinin kendi içideki zıt noktaları ile uyum içindedir. Rengin değeri ile müzikteki artikülasyon birbirlerine bağıntılı hareket etmektedirler.

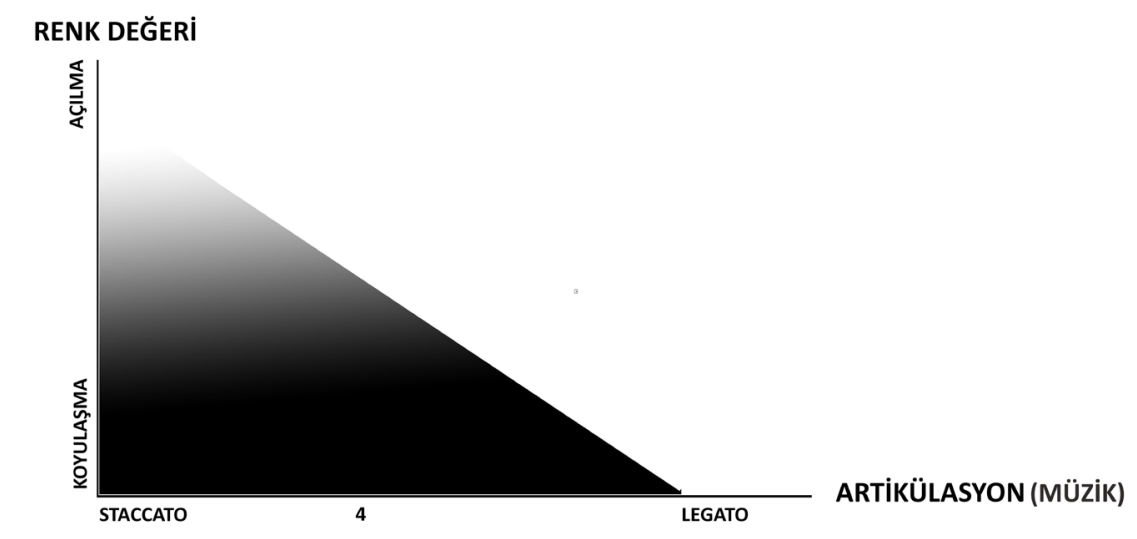

Şekil 15. Müzikte Artikülasyon ve Renk Değeri İlişkisi

"Biçim, Oran ve Müzik" üzerine yapılan çıkarımlara göre;

- Şekil 9'da görülen 9:15 - 9:28 dakikaları arası sahnelerin siyah beyaz biçimsel anlatımı üzerinden yapılan noktasal ve çizgisel analizin 4. karesinde ortaya çıkan sıklaşmış, tekrar eden noktaların oluşturduğu çizginin yoğun bir görsel doku algısına sahip oluşu, sahne ile eş zamanlı olan müziğin de benzer bir yaklaşımla duyuluyor oluşu, biçim ve müzik arasında bir ilişkilendirme yapılabileceğini düşündürmektedir. Aynı yaklaşım oranlar dikkate alındığında da görülebilmektedir. Şekil 10 'da aynı zaman aralı̆ıındaki sahnelerde, şekillerin oranı ele alındığında, 4. karedeki şekil algısı hiyerarşik bir düzen içerisindeki süreçte en büyük ebattadır. Müzik de sürecin başında sade ve piano giderken, 4. karede sforzando (güçlü atak) ile başlayarak, crescendo yapılmış, ses yükselerek müzik dinamiklerinde piano'dan for- tissimo'ya ulaşmıştır. Biçimlerin ölçü anlamında artması gibi, müzik ses yüksekliğinde de kademe kademe artış söz konusudur. Şekil 16'da sözü edilen biçim, oran ve müziğe dair gözlenen ilişki grafikleri görülmektedir. Film mekanındaki biçimin dinamikleşmesi ile melodi zenginleşmekte, biçim daha yalın oldukça, müzik sadeleşmektedir. Biçim ile müzikte melod arasında doğru orantı bulunmaktadır. Benzer ilişki oran ve müzikteki dinamiklerde de mevcuttur.
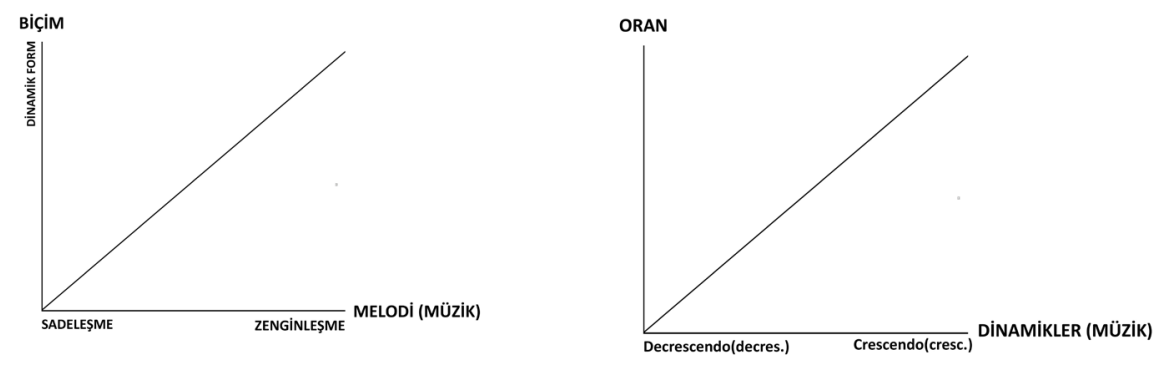

Şekil 16. Makaseller 9:15 - 9:28 Dakikalar Arası Sahnelerdeki Oran

- Şekil 11'de görünen filmin farklı dakikalarından alınan kareler içerisinden 1. karede yapının büyüklüğünü ve ihtişamını hissettiren bakış açısı ile eş zamanlı olarak müzikte de tizleşme ve crescendo dikkati çekmektedir. 2. karede ise mekanda yükseklik yerine derinliğin hissedildiği, insanın o derinlikte kücüldüğü noktada, yaylıların daha keskin, net ve tiz sesleri duyulmaktadır. 3. karede ise, ondan önceki sahnedeki müziğin kademe kademe yükselerek fortissimo'ya ulaşması, boş ve büyük bir hacme varıldığında, müziğin çok ani bir şekilde kesilmesi söz konusudur. Mekan kimsesizliğini, tüm hacminin sessizliği ile duyurabilmektedir. Filmdeki bu tarz insan ölçeğinin mekanla ilişkisinin açıkça hissedildiği sahnelerde müziğin de aynı oransal değiş̧imleri göstermesi, mekanla biçimsel anlamda bağdaştığını göstermektedir.

"Ritim ve Müzik" üzerine yapılan çıkarımlara göre;

- Hem müzikte hem de mimarlıkta tasarım ilkelerinde görülen ritm, görsel bir tekrar olarak tanımlanabilirken, müzikte de ritim işitsel bir tekrar olabilir, tekrar eden bir melodi ya da ritm öğesi olabilir düșüncesi ile yapılan değerlendirmede Şekil 12'deki sahnelere ait ritmik ve hızlı tempodaki müzik genel tasarlanmış yapıya uymaktadır. Bu bölümün yapısı bestecinin benzer br eseri olan "Simpsons" a benzemektedir. Bu tür parçalarda var olan mod hızlı tempolarda icra edildiğinde, hareketlilik hissini arttırmak için kullanılmaktadır (Majör tondaki 4. notayı yarım ses tizleștirerek oluşan gam. Örnek: Do majörde fa yerine fa\# kullanmak gibi). Müzik, duyulabilir saat 
sesi aracılığıyla yoğun bir ritimle başlamaktadır. Legato ve uzun notalı keman melodisi yoğun ritimleri kendi içinde barındırarak yol eksenini tariflemektedir. Arabaların hareketiyle yarış başlamaktadır. Bu yarıştan hareketle de oluşan ritim, sabit mekan düzenindeki ritim etkisini pekiştirmekte ve müzikle daha etkili bir biçimde entegre olmaktadır. Mekanda ritim ile müzikteki ritimin bu birlikteliğinin bu dakikalarda oldukça belirgin olması sebebiyle Şekil 17'deki grafiği çizmenin uygun olduğu düşünülmüştür.

\section{MEKANDA RITIM}

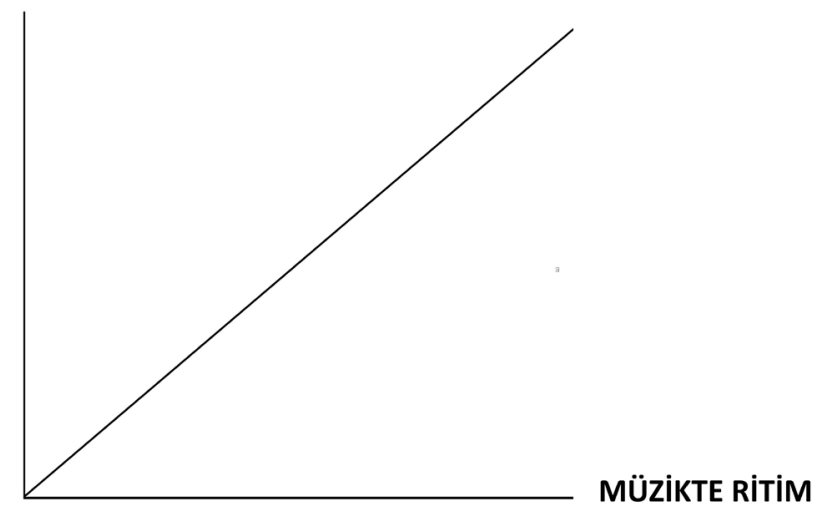

Şekil I7. Makaseller Film Mekanlarında Müzik ve Ritim İlişkisi

Sonuç olarak;

Incelenen örnek film karelerinde mekan ve müzik arasında biçimsel bağıntılar bulunmaya çalışılmıştır. Müziğin temel elemanları ile mekan düzenleme öğeleri arasında hangi öğelerin aracılığıyla bir bağıntı kurulacağı araştırılmıştır. Araştırmanın sonunda müzik, ilişkili mekan tasarım öğeleri ile belirli tasarım ilkeleri bağlamında değerlendirilmiş ve ilişki şemaları kurulmuştur. Bu şemalardan hareketle, yapılan değerlendirmeler ile "Filmde Mekan" ve "Filmde Müzik" eşleşmesinin sadece anlamsal değil, belirli kriterlerle eş zamanlı incelendiğinde biçimsel anlamda da eşleştikleri sonucuna varılmıştır. 


\section{Kaynakça}

Demirbaş, Ö. (2000). Düşsel Mekan, Yüksek Lisans Tezi, İstanbul Teknik Üniversitesi. Fen Bilimleri Enstitüsü, İstanbul.

Doğan, E. (2009). Sinema Filmlerinde İzleyicinin Etkilenmesinde Önemli Rol Oynayan Öğelerden Biri Olarak Film Müziği, Yüksek Lisans Tezi, T.C. İstanbul Üniversitesi Sosyal Bilimler Enstitüsü, Radyo Televizyon Sinema Anabilim Dalı, İstanbul.

Esen, H. (2000). Anayurt Oteli Filminde Zaman ve Mekan. Selçuk Iletişim, 3-I3.

Felix, M. N. ve Elsamahy, E. M. (20I6). "Visualizing Music Compositions in Architectural Conceptual Design”, Architecture And Planning Journal.

Güngör, I. H. (2020). Temel Tasar. 01: 21.

Kabataş, M. (20I7). “Müziğin Sinema Üzerine Etkisi”, Doğu Anadolu Sosyal Bilimlerde Eğilimler Dergisi, 37-48.

Otyakmaz, U. (2015). Renkler ve Müzik Arasındaki Ilişki, Yüksek Lisans Tezi, T.C. Beykent Üniversitesi Sosyal Bilimler Enstitüsü Illetişim Sanatları ve Tasarım Yüksek Lisans Programı Renk Kuramı, İstanbul.

\section{Internet Kaynakları}

Internet I: bilgibirikimi.net. (20I I, Haziran). Web: https://bilgibirikimi.net/20I I/06/26/ilksesli-film-ne-zaman-cevrilmistir/ adresinden 02 Ocak 2020 'de alınmıştır.

Internet 2: Çalıșır, G. (Aralık, 2015). FilmLovers. Web: https://www.filmloverss.com/edwardscissorhands-farkliligin-sessiz-cigligi/ adresinden 09 Ocak 2020'de alınmıştır.

Internet 3: Güleç, G. Çă̆lar. N. (20/4). Sinema ve Mimarlık Etkileşimi: Tım Burton Filmlerinde Modernizm Eleştirileri. Mimarlı. Web: http://www.mimarlikdergisi.com/index. cfm?sayfa $=$ mimarlik\&DergiSayi $=389 \&$ ReclD $=3303$ adresinden alınmıştır.

Internet 4: TDK. Güncel Türkçe Sözlük. Web: http://www.tdk.gov.tr/index.php?option=com gts\&arama = gts\&guid=TDK.GTS.5 / 387fbc5e4db5.2 I 78/357 adresinden 02 Ocak 2020'de alınmıştır.

Internet 5: Vikipedi. Web: https://www.wikizeroo.org/index.

php?q=aHROcHM6Ly90ci53aWtpcGVkaWEub3JnL3dpa2kvRmFudGV6aQ adresinden 05 Ocak 2020'de alınmıştır.
Internet 6: IMDB. Web: Burton, Tim. "Edward Scissorhands". (1995). https://www.imdb. com/title/tt0099487/.

\section{Görsel Kaynakları}

Görsel I: Klötzli'den akt. Çepel, N. (1992). Doğa-Çevre-Ekoloji ve İnsanlığın Ekolojik Sorunları. Istanbul: Altın Kitaplar Yayınevi, s.2I

Görsel 2-3: Balmori, D. , Sanders. J. (20II). Groundwork: Between Landscape and Architecture. New York: Monacelli Press, s. I08-109.

Görsel 4: https://www.urbangreenbluegrids.com/projects/landscape-park-duisburg-nord/ (Erişim tarihi: 26.03.2020).

Görsel 5: https://www.urbangreenbluegrids.com/projects/landscape-park-duisburg-nord/ (Erişim tarihi: 26.03.2020)

Görsel 6: https://scenariojournal.com/wp-content/uploads/201 I/07/0I_alt-LandscapeDesign-Eastern-Scheldt-Storm-Surge-Barrier-05-med.jpg (Erişim tarihi: 26.03.2020).

Görsel 7: https://www.e-architect.co.uk/images/jpgs/singapore/editt_tower_t020410_2.jpg (Erişim tarihi: 31.03.2020).

Görsel 8: https://www.archdaily.com/34/2/9/sportplaza-mercator-venhoevencs/5 /38bab5b 3fc4b If96000002-sportplaza-mercator-venhoevencs-photo?next_project = no (Erişim tarihi: 30.03.2020).

Görsel 9: https://www.archdaily.com/34/219/sportplaza-mercator-venhoevencs/5 /38bab6b3 fc4b I 76f000003-sportplaza-mercator-venhoevencs-photo (Erişim tarihi: 30.03.2020).

Görsel 10: https://www.archdaily.com/34/219/sportplaza-mercator-venhoevencs/5 /38baa6b $3 f c 4 b / 76 f 00000$ I-sportplaza-mercator-venhoevencs-photo?next project = no (Erişim tarihi: 30.03.2020)

Görsel 12: https://www.aksam.com.tr/ekonomi/kuzey-ankaraya- I 764-yeni-konut-dahageliyor/haber-168527 (Erişim tarihi: 30.03.2020).

Görsel 13-14-15-I6: F. Çağrı Kırmızıgül'ün arşivinden 